\title{
Negative pressure wound therapy by indigenous method: a decisive and cost-effective approach in management of open wounds
}

\author{
Neelam R. Charles, Apoorv Gupta*, Sanjay Datey, Rajat Lohia
}

Department of General Surgery, SAIMS, Indore, Madhya Pradesh, India

Received: 03 April 2016

Revised: 19 May 2016

Accepted: 03 June 2016

\section{*Correspondence:}

Dr. Apoorv Gupta,

E-mail: apoorvgupta2011@gmail.com

Copyright: ( ) the author(s), publisher and licensee Medip Academy. This is an open-access article distributed under the terms of the Creative Commons Attribution Non-Commercial License, which permits unrestricted non-commercial use, distribution, and reproduction in any medium, provided the original work is properly cited.

\section{ABSTRACT}

Background: The vacuum-assisted closure was pioneered by Dr Louis Argenta and Dr Michael Morykwas in 1993. It is a development from the standard surgical procedure, which uses vacuum-assisted drainage to remove blood or serous fluid from an operation site to provide a drier surgical field and control blood flow.

Methods: We carried out a prospective study of 50 patients on the role of negative pressure wound therapy (VAC) by indigenous method for open wounds cases. Study was conducted during the period from November 2013 to May 2015. Details of cases were recorded including history and wound characteristics.

Results: In our study the rate of granulation tissue increases significantly after successive application of VAC and no complications occurred following any VAC dressing. VAC dressing also provided the wound ready for SSG or flap rotation early as assessed by wound bed score. In financial terms VAC dressings by indigenous method is comparable to conventional dressings.

Conclusions: Vacuum assisted closure dressing was found to be totally safe. Thus, vacuum assisted closure dressing can be considered as a superior option in the management of chronic wounds. Also compliance of patient is good in vacuum assisted closure therapy.

Keywords: Vacuum-assisted, Granulation tissue, Chronic wounds

\section{INTRODUCTION}

Incidence of high velocity trauma is increasing day by day. As a consequence, open wounds are on an upswing. Despite of numerous evolvements in management techniques, management of open wounds still remains a challenge. Such wounds act as a hindrance in early definitive treatment owing to high infection and contamination rates. Thus management of such wounds becomes the primary mainstay.

Such wounds need to debrided thoroughly over and over and even after that a wait and watch strategy has to be employed before they can be definitely fixed.
Negative pressure wound therapy is one of the most important modes of treatment used in modern wound management. ${ }^{1-5}$ It utilizes the wound healing potential of an environment with sub-atmospheric pressure. The relevance of VAC lies in that it can significantly shorten the waiting interval of wound healing and make it possible to subject the patients with such wounds for definitive surgery as soon as possible.

Our study focuses over central India where the magnitude of patients comes from a group where cost is a big issue, indigenous VAC provides effective treatment in low cost.

In our study we have shown that a significantly low cost variant of VAC has given us with consistently 
comparable results at a price which is as much as 20 times lower than that of the conventional. This NPWT has showed excellent growth of granulation tissue in most of the cases. Most patients underwent split skin graft instead of flap cover which was more cost effective for the patient.

\section{METHODS}

We carried out a prospective study of 50 patients on the role of negative pressure wound therapy (VAC) by indigenous method for open wounds cases in which the wounds could not be primarily closed fearing chances of infection or/and inapt approximation credited to their size, were chosen for vacuum assisted dressing. All such patients with wounds including severely crushed limbs, surgical site infection, degloving injuries, traumatic amputations, wounds with bone or soft tissue exposure, pressure sore who were admitted in our hospital were offered VAC therapy and those who were willing, VAC was applied after taking all contraindications into account.

From November 2013 through May 2015 prior written and informed consent was obtained. Wounds were thoroughly debrided. Active bleed was controlled wherever necessary, generously washed and vacuum dressing was applied.

Standard procedure for dressing consisted of application of autoclaved pre-prepared polyurethane covered with an airtight drape and connected to a suction pump available at bed side in surgery ward with pressure of $125 \mathrm{~mm}$ of $\mathrm{Hg}$ with a ryles tube (no 12).

A ryles tube of size no 12 was fenestrated with small holes and was fixed to auto-claved foam which was cut according to the size the wound, by taking sutures. This whole was dipped in solution of $10 \%$ betadine and then applied over the wound. A cling drape was applied in such a way that it created an airtight compartment over the wound without being too tight or being too loose.

Routine protocol was to keep vacuum dressing for 48-72 hours. During which a cycle of 2 hours was followed- 1/2 hours of active suctioning and $11 / 2$ hours of no suctioning.

Dressings were opened after 48-72 hours and wound condition was clinically assessed and quantified. Assessments of these wounds were done on a regular basis by wound bed score. Assessment of rate of granulation was done on day $3^{\text {rd }}$, day $7^{\text {th }}$ and day $10^{\text {th }}$. Change of size (measured in $\mathrm{cms}$ by a placing a guaze piece over the wound and measuring its size) based on the rate of granulation, definitive surgical intervention (skin grafting, secondary closures and flap cover procedures) was done.

\section{Material required cost}

- $\quad$ Sterile sponge - Minimal cost 60 rupees

- Ryles tube- 40 rupees

- Cuticel- 150 rupees

- Cling drappe -35 rupees

- Gamzee- 40 rupees

- Roller Bandage-15 rupees

Total: 340 rupees

\section{Inclusion criteria}

- Wounds in the diabetic foot

- Acute and traumatic wounds

- Dehisced wound

- Pressure ulcers

- Chronic open wounds

- Venous stasis ulcers.

\section{Exclusion criteria}

- Fistulas or organs or body cavities

- Necrotic tissue in eschar

- Osteomyelitis (untreated)

- Malignancy in the wound

- Actively Bleeding wound

- Ischemic ulcers

- Patients on anticoagulants.

\section{RESULTS}

\section{Wound bed score}

Wound bed score is a classification system that scores the following parameters:

- Healing edges (wound edge effect)

- Presence of eschar

- Greatest wound depth/granulation tissue

- Amount of exudate amount

- Edema

- Peri-wound dermatitis

- Peri-wound callus and or fibrosis and

- Pink/red wound bed.

Each parameter receives a score from 0 (worst score) to 2 (best score), and all the parameter scores are added for a total score. Each wound can have a maximum score of 16 (the best score possible), to a minimum score of 0 (the worst score possible).

\section{Assessment of rate of granulation}

At presentation, the wound of the patient was assessed by measuring the maximum length and maximum width of the wound. 
Then on day $3^{\text {rd }}, 7^{\text {th }}$ and day $10^{\text {th }}$, the maximum length and maximum width of the granulation tissue covering the same wound was measured.

The length of granulation tissue (a) multiplied by breadth of granulation tissue (b) divided by length of wound (c) multiplied by breadth of wound (d) and whole multiplied by 100 . This gives the rate of granulation tissue in percentage.

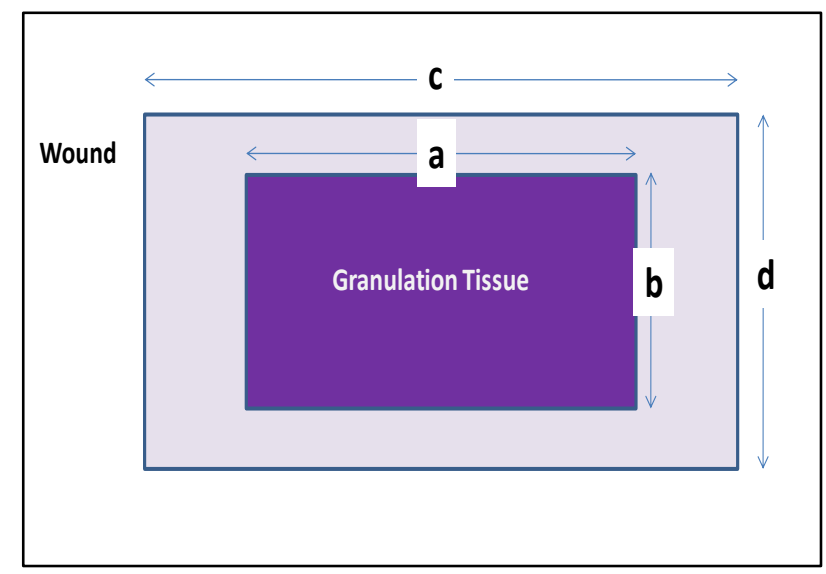

Figure 1: Assessment of rate of granulation.

Rate of granulation tissue $=$

$\frac{\text { Length } \times \text { breadth of granulation tissue }}{\text { Length } \times \text { breadth of wound }} \times 100$

Rate of granulation tissue $=$

$$
\frac{a \times b}{c \times d} \times 100
$$

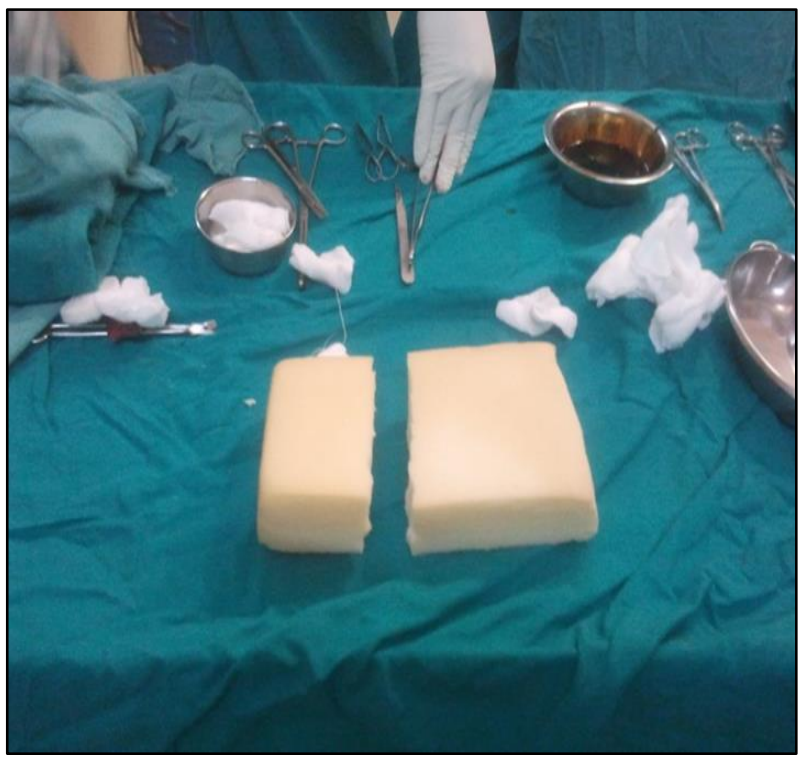

Figure 2: Cutting the sponge according to the size of the wound.

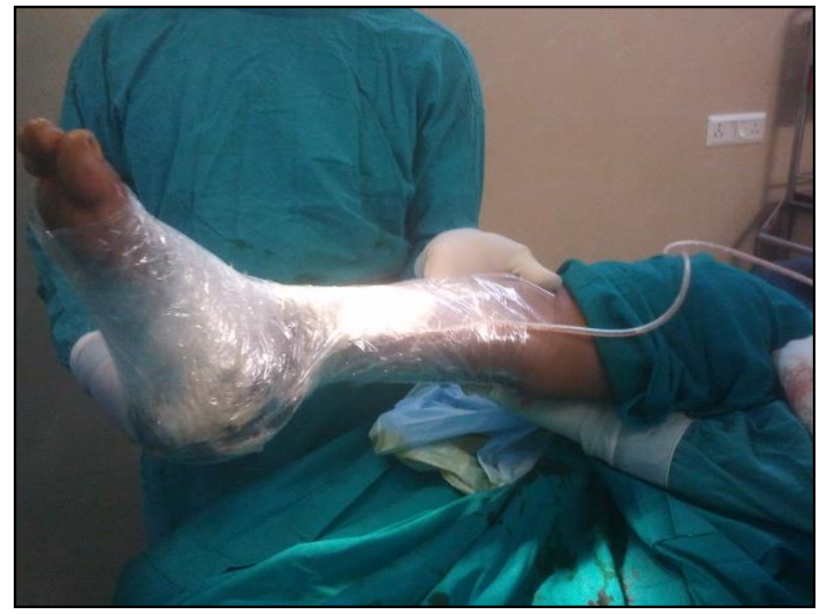

Figure 3: The cut sponge is fit into the wound with placing of Ryles tube above the sponge and covering the wound with cling drape thereby making a closed cavity.

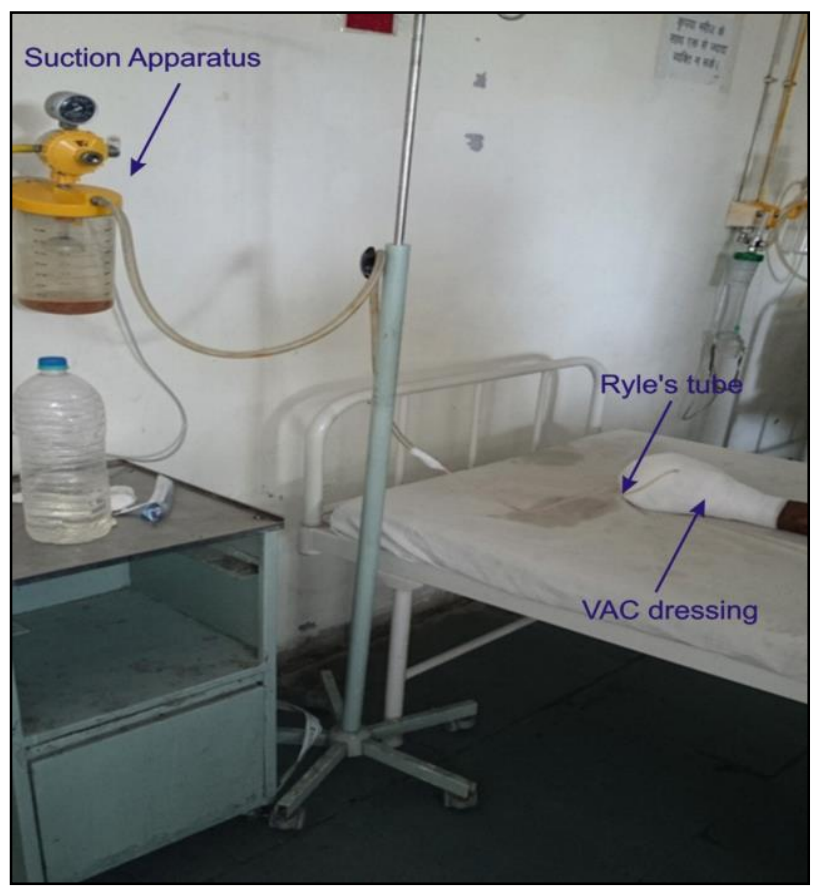

Figure 4: Connection of the tube to the suction apparatus thereby creating negative pressure of 150 mmHg.

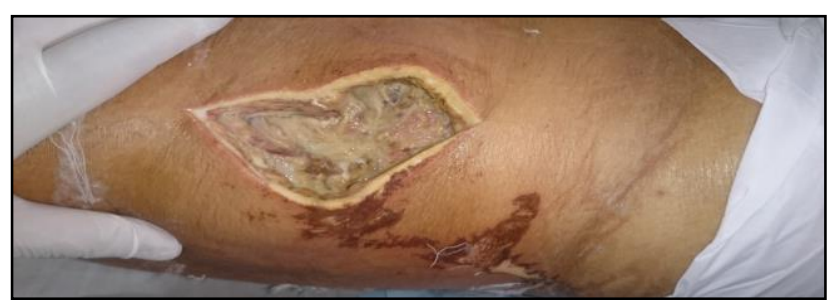

Figure 5: Pre Vac wound with discharging pus. 


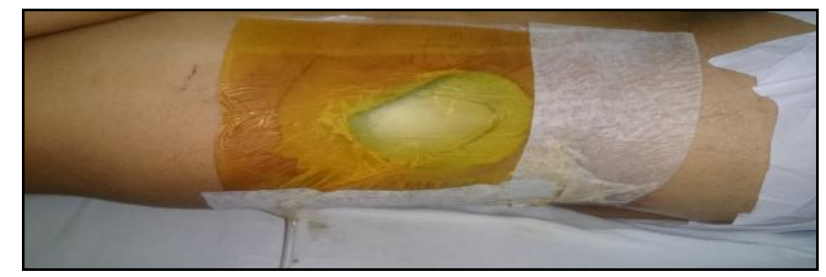

Figure 6: VAC applied.

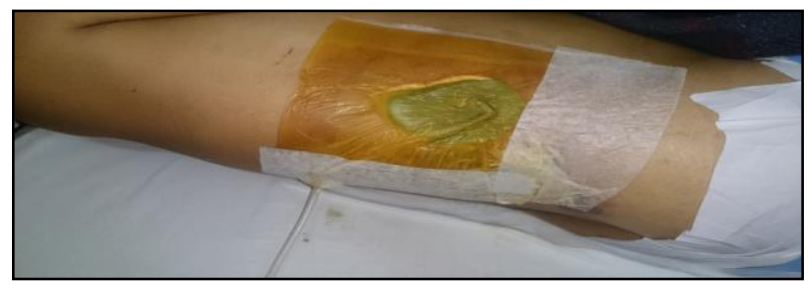

Figure 7: Contraction of the sponge as VAC is functioning.

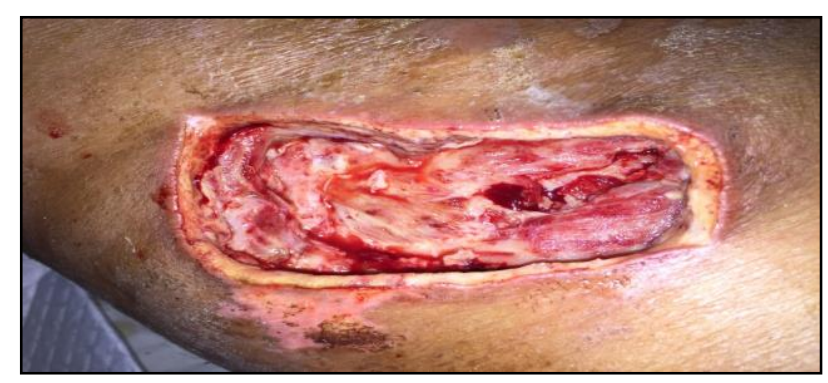

Figure 8: Final wound after three cycles of VAC.

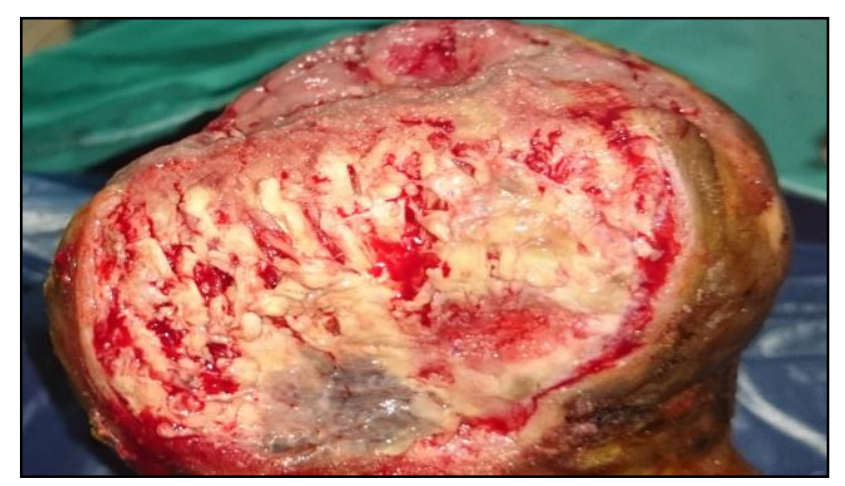

Figure 9: Pre-vacuum assisted closure.

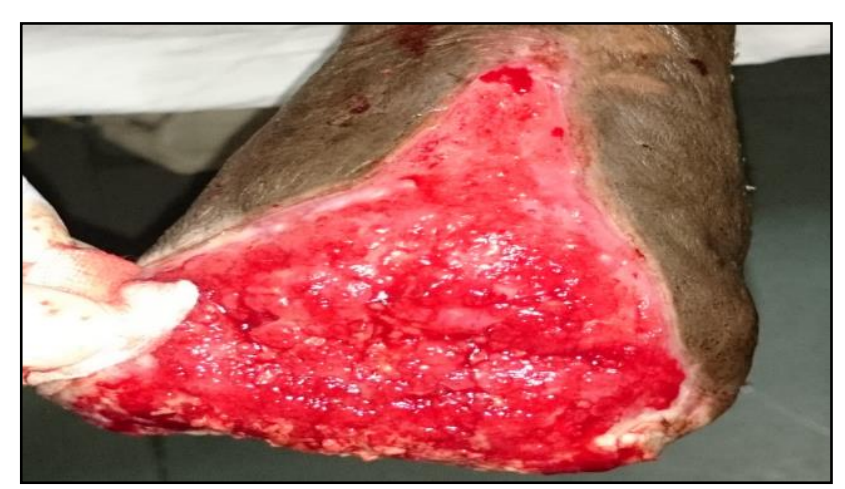

Figure 10: Post-VAC (after 2 VAC dressings).

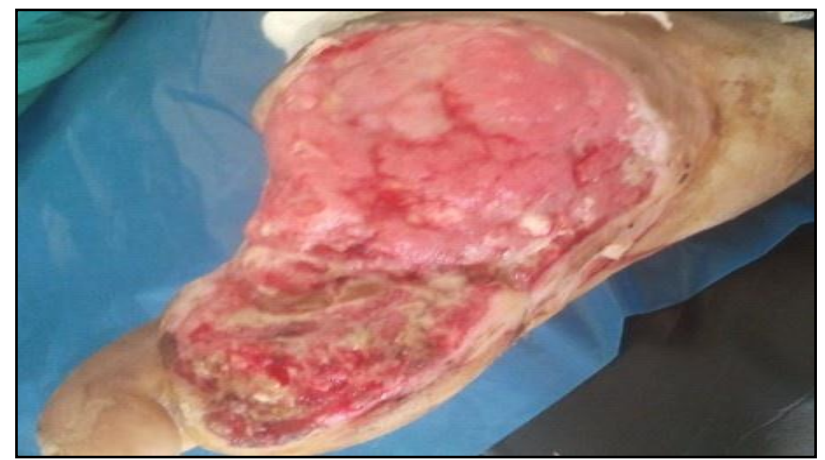

Figure 11: Pre-vacuum assisted closure.

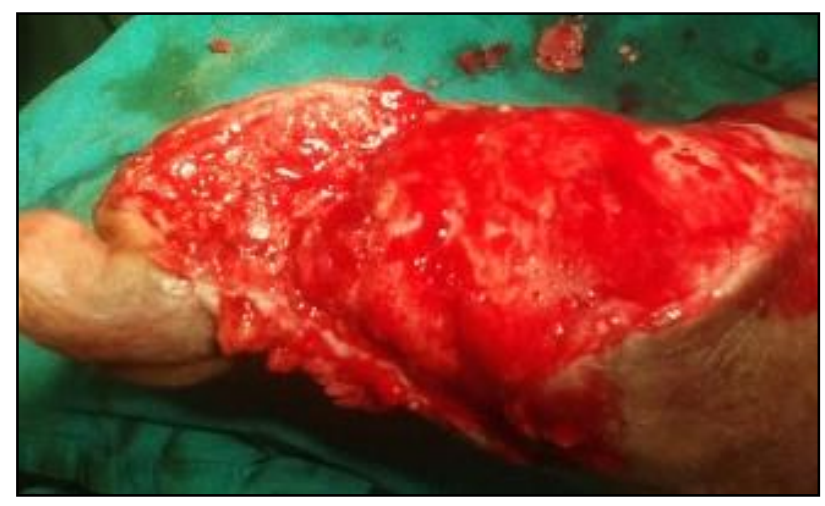

Figure 12: Post-VAC (after 3 VAC dressings).

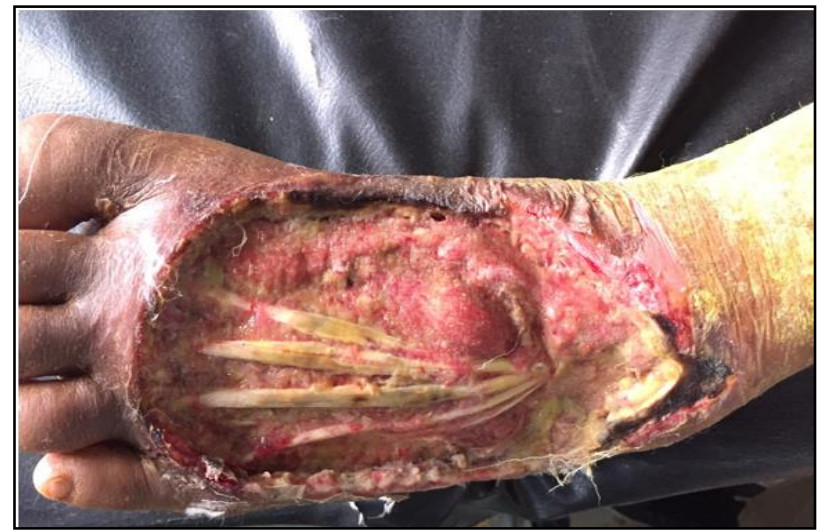

Figure 13: Pre-vacuum assisted closure.

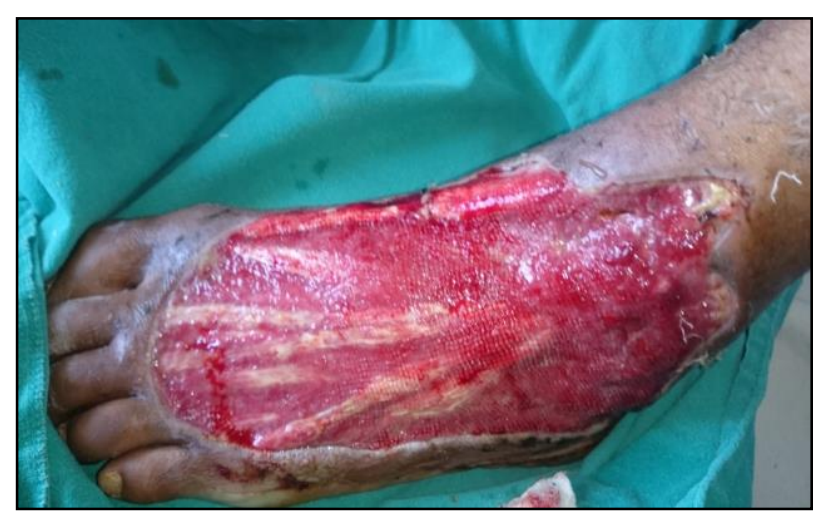

Figure 14: Post-VAC (After 2 VAC dressings). 
Table 1: Mean wound bed score at day-0, day-3, day-7 and day-10.

\begin{tabular}{|lllll|}
\hline Days & $\mathbf{N}$ & Mean & SD & Median \\
\hline Day-0 & 50 & 3.06 & 1.66 & 3.0 \\
\hline Day-3 & 50 & 6.14 & 1.74 & 6.0 \\
\hline Day-7 & 50 & 10.04 & 1.67 & 10.0 \\
\hline Day-10 & 48 & 12.81 & 1.76 & 13.0 \\
\hline
\end{tabular}

Mean wound bed score at day-0, day-3, day-7 and at day10. The mean wound bed score increased progressively in the successive VAC dressings.

Table 2: Age wise evaluation of wound bed score on Day-7.

\begin{tabular}{|lllll|}
\hline \multirow{2}{*}{ Age in years } & $\mathbf{N}$ & \multicolumn{3}{c|}{ Day-7 } \\
\hline$<=20$ years & 4 & 11.75 & 1.50 & 12.0 \\
\hline 21-40 years & 14 & 10.28 & 1.54 & 10.5 \\
\hline 41-60 years & 22 & 9.86 & 1.93 & 10.5 \\
\hline$>60$ years & 10 & 9.40 & 0.52 & 9.0 \\
\hline Total & $\mathbf{5 0}$ & $\mathbf{1 0 . 0 4}$ & $\mathbf{1 . 6 7}$ & $\mathbf{1 1 . 0}$ \\
\hline
\end{tabular}

In our study there were 4 patients of age less than 20 years and they had mean wound bed score of 11.75 which is best among all the age groups. There were 10 patients in age group of more than 60 years and they had mean wound bed score of 9.40 which is worse among all other age group.

Table 3: Gender wise distribution of patients.

\begin{tabular}{|lll|}
\hline Gender & No. & Percentage \\
\hline Male & 39 & 78.00 \\
\hline Female & 11 & 22.00 \\
\hline Total & $\mathbf{5 0}$ & $\mathbf{1 0 0 . 0 0}$ \\
\hline
\end{tabular}

In our study, there were $39(78 \%)$ male patients and 11 (22\%) female.

Table 4: Distribution according to organisms cultured from wound.

\begin{tabular}{|lll|}
\hline Organism cultured & No. & Percentage \\
\hline No organism & 16 & 32.0 \\
\hline E. coli & 1 & 2.0 \\
\hline E. coli and proteus & 1 & 2.0 \\
\hline K. pneumoniae & 5 & 10.0 \\
\hline MRSA & 5 & 10.0 \\
\hline P. aeruginosa & 5 & 10.0 \\
\hline Proteus & 2 & 4.0 \\
\hline S. aureus & 10 & 20.0 \\
\hline S. epidermidis & 2 & 4.0 \\
\hline S. pneumoniae & 3 & 6.0 \\
\hline Total & $\mathbf{5 0}$ & $\mathbf{1 0 0 . 0 0}$ \\
\hline
\end{tabular}

In our study the most common organism found to be cultured was Staphylococus aureus and $32 \%$ of wounds showed no growth of organism.

Table 5: Etiology of wounds.

\begin{tabular}{|c|c|c|c|c|}
\hline \multirow{2}{*}{ Etiology } & \multicolumn{4}{|c|}{ Day-7 } \\
\hline & $\mathbf{N}$ & Mean & SD & Median \\
\hline Abscess & 1 & 11.0 & - & 11.0 \\
\hline Bed sore & 3 & 9.0 & 2.0 & 9.0 \\
\hline Non healing ulcer & 1 & 6.0 & - & 6.0 \\
\hline Cellulitis & 8 & 10.63 & 1.69 & 10.5 \\
\hline Diabetes & 19 & 9.68 & 1.38 & 10.0 \\
\hline Insect bite & 2 & 10.0 & 1.41 & 10.0 \\
\hline Surgical site infection & 2 & 10.5 & 0.71 & 10.5 \\
\hline Trauma & 13 & 10.46 & 1.81 & 10.0 \\
\hline Venous ulcer & 1 & 12.0 & - & 12.0 \\
\hline Total & 50 & 10.04 & 1.67 & 10.0 \\
\hline
\end{tabular}

In our study the majority $(30 \%)$ of patients had diabetes with mean wound bed score of 9.68. The mean wound bed score was found to be best with cellulitis patient with a mean of 10.63 .

Table 6: Mean rate of granulation tissue at day-3, day-7 and day-10.

\begin{tabular}{|lllll|}
\hline Days & N & Mean & SD & Median \\
\hline Day-3 & 50 & 22.56 & 11.30 & 21.50 \\
\hline Day-7 & 50 & 46.58 & 11.29 & 45.50 \\
\hline Day-10 & 47 & 65.26 & 10.60 & 67.00 \\
\hline
\end{tabular}

In our study the rate of granulation tissue increases significantly after successive application of VAC.

Table 7: Mean wound bed score of day-7 in diabetic and non-diabetic patients.

\begin{tabular}{|lllll|}
\hline Patients & N & Mean & SD & Median \\
\hline Diabetic & 22 & 9.73 & 1.32 & 10.0 \\
\hline Non-diabetic & 28 & 10.29 & 1.88 & 10.0 \\
\hline Total & $\mathbf{5 0}$ & $\mathbf{1 0 . 0 4}$ & $\mathbf{1 . 6 7}$ & $\mathbf{1 0 . 0}$ \\
\hline
\end{tabular}

In our study the most common etiological factor came out to be diabetes mellitus and the mean wound bed score at day-7 is lower in diabetic patients in comparison to nondiabetic patients.

\section{DISCUSSION}

Since its first application NPWT has been used widely in the treatment of chronic and acute wounds. Many indications for the use of NPWT have been added since its first use. In our study we have included patients with acute traumatic injuries of the foot and certain open injuries. The mechanism of action of NPWT is it causes strain and stimulates cellular proliferation. It also causes mechanical evacuation of interstitial fluid. This in turn 
leads to increased micro circulation and there by secondary necrosis is reduced.

The concept of applying a sub-atmospheric environment on wounds to accelerate the healing process came into practice in 1993 and was first described by Fleischmann et al. ${ }^{6}$

The fundamental principle behind vacuum assisted closure dressing is the application of sub-atmospheric pressures ranging from -125 to $-200 \mathrm{mmHg}$ at the wound bed. ${ }^{6,7}$

Smith et al, in a retrospective review, concluded that with careful subsequent management good patient outcomes could be achieved and recommended vacuum assisted closure as the treatment method of choice for open abdomen management and temporary abdominal closure. ${ }^{9}$

\section{Mean age of the patients}

In our present study, mean age of patients is 46.5 years.

\section{Disease of the patient}

In our present study most common etiological presentation is Diabetic ulcer.

Similarly, study done by Francis TL et al found that most common etiological presentation was diabetic ulcer. ${ }^{10}$

\section{Most common organism on culture}

In our present study most common organism on culture is Aureus S.

A study conducted by Weed, Tonja MD; Ratliff, Catherine RN, PhD; Drake, David B. MD Annals of Plastic Surgery: March 2004 - Volume 52 - Issue 3 - pp 276-279.

In this study they concluded that negative pressure wound therapy has become an accepted treatment modality for acute and chronic wounds with accelerated healing rates observed. It has been previously reported that this therapy enhances bacterial clearance, which may account for the wound healing effects noted. We retrospectively reviewed 25 patients' charts undergoing wound VAC (vacuum assisted closure device; KCI International, San Antonio, TX) therapy with serial quantitative cultures and found that there is not a consistent effect of bacterial clearance with the wound VAC.

\section{Rate of granulation}

In our present study the rate of granulation tissue increases significantly after successive application of VAC.
Similar study done by Argenta, Louis C. MD; Morykwas, Michael J. PhD Three hundred wounds were treated: 175 chronic wounds, 94 subacute wounds, and 31 acute wounds. Two hundred ninety-six wounds responded favorably to sub-atmospheric pressure treatment, with an increased rate of granulation tissue formation.

\section{Duration of hospital stay}

In our study the mean duration of hospital stay is 18.84

Study done by Francis TL et al the mean hospital stay was 32.64 $\pm 13.81(\mathrm{SD})$ days.

\section{Complications}

In our study no complications occurred following any VAC dressing.

Study conducted by Francis TL et al concluded that there were no complications during the application of dressings, skin grafting or in the postoperative period.

\section{Mean age of the patients}

In our present study, mean age of patients is 46.5 years.

\section{Disease of the patient}

In our present study most common etiological presentation is Diabetic ulcer.

Similarly, study done by Francis TL et al found that most common etiological presentation was diabetic ulcer.

\section{Most common organism on culture}

In our present study most common organism on culture is Aureus S.

A study conducted by Weed, Tonja MD; Ratliff, Catherine RN, PhD; Drake, David B. MD Annals of Plastic Surgery: March 2004 - Volume 52 - Issue 3 - pp 276-279

In this study they concluded that negative pressure wound therapy has become an accepted treatment modality for acute and chronic wounds with accelerated healing rates observed. It has been previously reported that this therapy enhances bacterial clearance, which may account for the wound healing effects noted. We retrospectively reviewed 25 patients' charts undergoing wound VAC (vacuum assisted closure device; KCI International, San Antonio, TX) therapy with serial quantitative cultures and found that there is not a consistent effect of bacterial clearance with the wound VAC. 


\section{Rate of granulation}

In our present study the rate of granulation tissue increases significantly after successive application of VAC.

Similar study done by Argenta, Louis C. MD; Morykwas, Michael J. PhD Three hundred wounds were treated: 175 chronic wounds, 94 subacute wounds, and 31 acute wounds. Two hundred ninety-six wounds responded favorably to sub-atmospheric pressure treatment, with an increased rate of granulation tissue formation.

\section{Duration of hospital stay}

In our study the mean duration of hospital stay is 18.84

Study done by Francis TL et al the mean hospital stay was $32.64 \pm 13.81$ (SD) days.

\section{Complications}

In our study no complications occurred following any VAC dressing.

Study conducted by Francis TL et al concluded that there were no complications during the application of dressings, skin grafting or in the postoperative period.

\section{Limitations of the study}

The quantitative assessment of post-operative parameters like wound contraction, pain and residual raw ulcer area was also not included in the present study, which if included, might have given a much better analysis of the efficacy of topical negative pressure moist dressings (VAC) .

Despite recent clinical success with the use of vacuumassisted closure (VAC) in a variety of wound types, problems may occur with the application of VAC system in certain areas of the body. The main limitation occurs when attempting to maintain an airtight seal over irregular surfaces surrounding a wound. For example, application of the adhesive drape and creation of a seal are particularly difficult in the hip and perineum.

In addition, wounds of the lower extremity can occur in multiple sites, posing the problem of providing a vacuum dressing to more than one wound from one suction pump machine.

\section{CONCLUSION}

In our present study it was concluded that the rate of granulation tissue formation is good with vacuum assisted closure. Also compliance of patient is good in vacuum assisted closure therapy.
VAC dressing also provided the wound ready for SSG or flap rotation early as assessed by wound bed score.

Vacuum assisted closure dressing was found to be totally safe, although technically demanding. Thus, vacuum assisted closure dressing can be considered as a superior option in the management of chronic wounds.

Some wounds specifically over perineum and around hip joint are difficult for application for vacuum assisted closure of wounds.

Thus, we conclude that the surgeon's discretion is very much needed in VAC being the choice of dressings in certain wounds and where there is much difficulty in performing VAC dressings, the conventional dressings should be the choice.

\section{Funding: No funding sources}

Conflict of interest: None declared

Ethical approval: The study was approved by the institutional ethics committee

\section{REFERENCES}

1. Centers for disease control and prevention. National diabetes fact sheet: general information and National estimates on diabetes in the United States, 2005. Atlanta, GA, U.S. Department of Health and Human Services, Centers for Disease Control and Prevention; 2005.

2. Guideline for management of wounds in patients with lower-extremity arterial disease. Glenview, IL, Wound Ostomy and Continence Nurses Society; 2002.

3. Saxena V, Hwang CW, Huang S, Eichbaum Q, Ingber D, Orgill DP. Vacuum assisted closure: micro deformations of wounds and cell proliferation. Plast Reconstr Surg. 2004;114:108696.

4. Armstrong DF, Lavery LA. Negative pressure wound therapy after partial diabetic foot amputation: a multicentre randomized controlled trial. Lancet. 2005;366:1704-10.

5. Singh N, Armstrong DG, Lipsky BA. Preventing foot ulcers in patients with diabetes. JAMA. 2005;293:217-28.

6. Fleischmann W, Strecker W, Bombelli M, Kinzl L. Vacuum sealing as treatment of soft tissue damage in open fractures. Unfallchirurg. 1993;96(9):488-92.

7. Mullner T, Mrkonjic L, Kwasny O, Vecsei V. The use of negative pressure to promote the healing of tissue defects: a clinical trial using the vacuum sealing technique. Br J Plast Surg. 1997;50(3):1949.

8. Pham CT, Middleton P, Maddern G. Vacuumassisted closure for the management of wounds: an accelerated systematic review. ASERNIP-S Report No. 37. Adelaide, South Australia: ASERNIP-S, December 2003. Available at 
http://www.ncbi.nlm.nih.gov/pubmedhealth/PMH00 20085/.

9. Smith LA, Barker DE, Chase CW, Somberg LB, Brock WB, Burns RP. Vacuum pack technique of temporary abdominal closure: a four-year experience. Am Surg. 1997;63(12):1102-7:1107-8.
10. Francis TL, Ravikrishnan J, Satish Rao BS, Divakar $\mathrm{SH}$, Shetty SR, Leo MT. A comparative study of the efficacy of topical negative pressure moist dressings and conventional moist dressings in chronic wounds. Indian Journal of Plastic Surgery. 2007;40(2):133-40.

Cite this article as: Charles NR, Gupta A, Datey S, Lohiya R. Negative pressure wound therapy by indigenous method: a decisive and costeffective approach in management of open wounds. Int Surg J 2016;3:1399-406. 